\title{
UK data and analysis for shale gas prospectivity
}

Nigel Smith, Paul Turner \& Gareth Williams

British Geological Survey, Kingsley Dunham Centre, Nicker Hill, Keyworth NG12 5GG, njps@bgs.ac.uk.

Words 5884, References 54, Table 1, Figures 7

UK Shale Gas (Abbreviated title)

\section{Abstract}

Organic-rich shale maycontains significant amounts of gas held within fractures and micro-pores and adsorbed onto organic matter. In the US shale gas extracted from regionally extensive units such as the Barnett Shale currently accounts for $\sim 6 \%$ of gas production. Shale gas prospectivity is controlled by the amount and type of organic matter held in the shale, thermal maturity, burial history, microporosity and fracture spacing and orientation.

The main UK organic-rich shale sequences have been mapped at the surface and in the subsurface using a combination of outcrop, well and seismic data. Potential targets range in age from Cambrian to the late Jurassic: younger shales have been excluded because they have not reached the gas window, but they may possess a biogenic gas play. A GIS showing the distribution of potential reservoir units has been combined with information on hydrocarbon shows, thermal maturity, fracture orientation, gas composition and isotope data to identify potentially prospective areas for shale gas in the UK. These include Lower Palaeozoic shale basins on the Midland Microcraton, Mississippian shales in the Pennine Basin and Pennsylvanian shales in the Stainmore and Northumberland basin system. Keywords

Shale, gas, maturity, thickness, source rock and reservoir 
Organic-rich shale contains significant amounts of gas held within fractures and micro-pores and adsorbed onto organic matter. In the US, shale gas extracted from regionally extensive units such as the Barnett Shale account for $\sim 6 \%$ of gas production. The success of North American shale gas exploitation (over 28000 wells producing 380 bcf per year) has stimulated significant interest in identifying potential reservoirs throughout the world. Selley $(1987,2005)$, farsightedly, advocated shale gas exploration in the UK, based on Upper Devonian gas fields of the Appalachian basin, which have been producing since 1821. However in the past decade the Mississippian Barnett Shale of the Fort Worth Basin has become the most productive shale gas reservoir in the US. The Barnett Shale provides a good analogue for potential shale gas plays in the UK, which has thick Mississippian shales both on and offshore, therefore the geology and geochemistry of the Barnett Shale are discussed briefly below.

\section{The Barnett Shale}

The Barnett Shale Formation (354 - $323 \mathrm{Ma}$ ) of the Fort Worth Basin is up to $300 \mathrm{~m}$ thick and underlies an area of $\sim 13,000 \mathrm{~km}^{2}$. It contains c. 2.5 trillion cubic feet of proven gas reserves held in a low porosity and permeability shale matrix. Permeability is in the micro-nanoDarcy range and porosity rarely exceeds 6\% (Bowker 2007): consequently the Barnett Shale Formation is slightly overpressured, with formation pressures in excess of 4000 psi (Frantz et al. 2005).

The Fort Worth Basin shows a northward thickening, half-graben like structure, but is bounded by reverse faults against the Lower Palaeozoic Muenster Arch (part of the Southern Oklahoma Aulacogen). The Mississippian Barnett Shale unconformably overlies Ordovician strata and can be subdivided into two units, the Upper and Lower Barnett, separated by the Forestburg Limestone. The upper shale unit is overlain by the Marble Falls Limestone, also of Mississippian age, which is conformable with a thick succession of overlying Pennsylvanian sediments. Sedimentary structures suggest that the main shale units were deposited by distal turbidity flows in a sediment-starved anoxic basin environment. The Carboniferous sequence is truncated by a Cretaceous supercrop above the Variscan unconformity. The Ouachita (Variscan) fold belt lies at right angles to the Muenster Arch and impinges on the Fort Worth Basin in the southeast. 
The main factors controlling prospectivity of the Barnett are the thermal maturity, thickness and total organic carbon (TOC) content of the shale (Zhao et al. 2007). Local and regional structures such as joints, folds and faults control fracture porosity and thus influence production potential at a variety of scales. Most natural fractures are sealed but these can potentially be exploited by artificial fracturing techniques (Bowker 2007) to improve flow rates around a well. Siltstone bands and chert nodules can also affect prospectivity locally.

The Newark East shale gasfield lies up-dip west of the depocentre of the Barnett Shale in the wedge between the Muenster Arch and the Ouachita (Variscan) fold belt (Pollastro et al. 2004). Similarly the Big Sandy shale gasfield in eastern Kentucky lies over the thickest part of the Devonian Brown Shale, which is bounded to the SE by the Pine Mountain thrust (Ray 1976) of the Appalachian (Variscan) fold belt.

\section{UK's closest tectonic analogue}

Satellite basins of the Worcester Graben (Fig. 1) beneath the Bristol Coalfield and in Berkshire to the east (Mississippian strata are feebly developed in the latter area) provide the closest UK tectonic analogues to the Fort Worth Basin. They are small foreland basins preserved between the Variscides and the Worcester Graben. The latter formed in response to extensional faulting during the Lower Palaeozoic and inverted during the Variscan Orogeny comparable with the Southern Oklahoma Aulacogen (Smith 1993, Smith \& Rushton 1993). The Bristol depocentre lacks the acreage of the Fort Worth Basin but contains the Lower Limestone Shale Group, conformably overlying Devonian and of roughly equivalent age (359 - $327 \mathrm{Ma}$ ), to the Barnett Shale Formation. Few wells and no maturity or geochemical data are available though, and seismic is sparse.

It is important to note, however, that there are significant differences between shale gas plays developed in different basins in the US. Consequently this contribution considers the main generic controls on shale gas prospectivity identified in key US plays (see above) in a regional UK context, before identifying potential exploration targets.

\section{Petrology, Petrophysics and Geochemistry of Potential Source Rocks}


Organic-rich sediments have a lower density, lower acoustic velocity, higher porosity, higher resistivity and higher gamma-ray values compared to sedimentary units of equal compaction and comparable mineralogy. Potential source rocks can thus be readily identified on well logs, provided they are rich in organic matter. For example, the Arnsbergian Sabden Shale typically exhibits anomalously low sonic transit times and high gamma ray values in the Pennine Basin (Smith et al. 2005). Classification schemes based on wireline logs break down at high water saturations because water and organic material have comparable densities: the specific gravity of organic matter is about $0.95-1.05 \mathrm{~g} \mathrm{~cm}^{-3}$ (Stocks \& Lawrence 1990).

The stratigraphy and distribution of key organic-rich shale formations identified on well logs are summarised in Figure 1. In the UK, organic-rich shales can be subdivided into three broad stratigraphic groups belonging to the Lower Palaeozoic (principally Cambrian), Mississippian and Jurassic (of Liassic, Oxfordian and Kimmeridgian age).

\section{Pre-Carboniferous black shales}

Black shales are developed in the Upper Cambrian, Upper Ordovician and Lower Silurian strata of the UK (Leggett 1980). Ordovician and Silurian shales are largely restricted to deeper basins, while Cambrian black shale deposits are also found on the Midland Microcraton. Unexplained gas shows in the Welsh Borderland and Welsh Caledonides may have been sourced from concealed Lower Palaeozoic black shales.

Upper Cambrian black shales outcrop in small inliers close to zones of uplift, but seismic data suggest that they are widespread in the subsurface. Shales of this age were proved by the Fowlet Farm and Fownhope boreholes SW of the Malverns (Fig. 1, Earp \& Hains 1971). In these boreholes, 68 $\mathrm{m}$ of black shale has been intruded by dolerite sills; the shales have high gamma ray values and represent a potential source rock. Outcrop measurements of TOC support this interpretation, with values of $\sim 5 \%$ recorded by Parnell (1983). 
In Shropshire $\sim 5 \mathrm{~m}$ of black shales with bituminous limestone concretions are underlain by $20 \mathrm{~m}$ of dark grey shale. To the northeast at Lilleshall a small outcrop and borehole (Fig. 1) revealed c. $53 \mathrm{~m}$ of black, pyrite-rich shale lying unconformably on Lower Cambrian strata (Rushton et al. 1988). Unfortunately TOC and thermal maturity analyses were not made in this borehole. The Lilleshall deposits may be the erosional remnants of a tilted fault-block high (Middle Cambrian strata are missing, Smith \& Rushton 1993), with a half-graben basin developed against the Brewood Fault to the east (Smith et al. 2005).

In the area around Nuneaton the Merevale boreholes encountered c. 60 m of condensed black mudstone (Monk’s Park Shales, Taylor \& Rushton 1971). TOC values exceeded 2\% and sulphur content reached 10\%; phosphate was present in the form of scattered nodules. These deposits may provide some shale gas potential. Conversely, the Cooles Farm borehole tested part of the Worcester Graben (Fig. 1). It was drilled into Cambrian strata but did not record the presence of any Upper Cambrian high gamma shale units.

Ordovician and Silurian shale units seem to have less potential as a shale gas play, based on limited drilling. In the Fownhope well only a short section of a Llandovery-age clay approached gamma ray values indicative of a potential source rock. A borehole drilled at Usk (east of Usk Anticline in Fig. 1) penetrated no potential source rocks in the Lower Palaeozoic, although minor gas shows occurred in some sandstone units. However this well was drilled on a structural high missing a large section of Llandovery sequence where black shales might have formed in the depocentre beneath the Usk Anticline. A black shale facies of this age is known in Welsh Caledonides to the west (Leggett 1980).

UK Lower Palaeozoic black shales often show preferential enrichment of various heavy elements including As, Co, Cr, Cu, Mo, Ni, Pb, S, U and V (Leggett 1980, Jones \& Plant 1989). This is particularly true of the Upper Cambrian interval and appears to be associated with organic matter.

A few samples from a BGS borehole in the Midlands suggest a porosity of 5-10\% survives down to a depth of $1000 \mathrm{~m}$ in Lower Cambrian (Poole 1978). In many places these rocks have been subjected to 
significant comnpaction, intrusion and tectonism and primary porosity would be expected to be very low. There is, however scope for induced fracture permeability in these rocks.

In contrast to the Appalachian Basin in the US, there are no Devonian black shale sequences in the Variscan foreland of the UK. Lacustrine shale deposits are present in the Middle Devonian of the Orcadian Basin in Scotland (Fig. 1): TOC values typically average $1.4 \%$. Thermal maturity is variable, but these rocks largely fall within the oil window or are overmature (in the vicinity of underlying intrusions), and offshore they probably helped charge the Beatrice Oilfield (Hillier \& Marshall 1992). Two boreholes drilled at Dounreay proved up to $150 \mathrm{~m}$ of interbedded high gamma shale beds.

\section{Carboniferous Black Shales}

Mississippian shale units offer the best potential for shale gas exploration in the UK because they have sourced hydrocarbons, have high TOCs (Armstrong et al. 1997) and were deposited in deep half graben, within the Pennine Basin in northern England (Fraser et al. 1990). The younger (Namurian) of these shales are more widely deposited as the extensional half graben subsidence was transforming to a more regional thermal subsidence.

\section{Gas Content and Kerogen Type}

The gas content of Coal Measures strata was measured by the National Coal Board (Creedy 1989). Carbonaceous mudstones (including marine bands) contained 0.18 - $0.63 \mathrm{~m}^{3} / \mathrm{t}$ gas; whereas noncarbonaceous mudstones contained between 0.009 to $0.1 \mathrm{~m}^{3} / \mathrm{t}$. Budge (1932) reported methane adsorption of $1.8 \mathrm{~m}^{3} / \mathrm{t}$ in carbon-rich Coal Measures mudstone and $0.25 \mathrm{~m}^{3} / \mathrm{t}$ in a black shale from the South Wales Coalfield. Ferguson (1984) measured methane values of up to $46000 \mathrm{ppb}$ in the Carboniferous Limestone of northern England, near to mineralized areas on the Alston Block: there also appeared to be an association between base metal vein mineralization in Derbyshire and the adjacent shale-rich Pennine Basin half graben (Plant \& Jones 1989). Ewbank et al. (1993) noted that Alportian-Pendleian mudstones exposed at outcrop in the Edale Gulf area predominantly contained gas-prone Type III kerogen, whereas mudstone samples form a Widmerpool Gulf well (Arnsbergian 
age), the Goyt Trough and various Visean mudstones were dominated by Type II kerogen (gas and oil prone).

\section{Total Organic Carbon (TOC)}

Namurian marine shales have generally higher TOC values (over 4\%) compared to non-marine shales (Spears \& Amin 1981), which have an average value of around 2\% (Fig. 2). Maynard et al. (1991) found that two Namurian black shale marine bands had a TOC content of between $10-13 \%$, whereas values within interbedded strata ranged between 2 and 3\%. The Namurian Holywell Shale, source rock for the southern East Irish Sea and Formby hydrocarbon fields, has TOC values ranging from 0.7-5\%, with an average of 2.1\% (Armstrong et al. 1997). The lower part of this formation gave an average of 3\% TOC and pyrolsate yields of $7 \mathrm{~kg} /$ tonne $^{-1}$.

\section{Thermal Maturity}

Vitrinite reflectance (\%Ro) measurements at outcrop and in boreholes provide a widely accepted proxy for thermal maturity and hydrocarbon generation. These are shown for the nearest value to the basal Namurian (Fig. 3, at Knutsford it is probably within the Westphalian D). Maturity zones can be divided into immature for oil, within the (migrated) oil window, within the (migrated) gas window and over-mature for hydrocarbons. The oil window is normally considered to fall between 0.6 and 1.3\% Ro, although it varies according to kerogen type. There is no agreement on the lower limit of the gas window which has variously been put at 2\% Ro (Landes 1967), 3\% Ro (Dow 1977), 3.2\% Ro (Dow \& Connor 1982) and 5\% Ro (Hood et al 1975). In this study a value of $1.1 \%$ Ro has been used to differentiate maturity levels (Fig. 3), because this value defines the limit of the Newark East gasfield in the Barnett Shale (Pollastro et al. 2004).

\section{Porosity, Permeability and Fracture Porosity}

Limited porosity data from BGS boreholes in the southern Midlands suggest that porosities of 5-10\% survive to a depth of $1000 \mathrm{~m}$ in Upper Palaeozoic shales (see Figure 4 and-Poole 1977, 1978). Coal

Measures mudstones, seat-earths and siltstones have measured permeability values in the range 0.000004-0.007 mD (Oldroyd et al. 1971). 
Joints, developed in the limestone platforms of Derbyshire and the Askrigg Block (Moseley \& Ahmed 1967), are predominantly sub-vertical and perpendicular to bedding. Joint development preceded the main phase of movement on the main fault zones and they are frequently mineralised. Well-bedded marine shales tend to have a high joint density, in contrast to mudstones and sand-rich shale units. Minor joints are more difficult to distinguish in argillaceous rocks, but master joints persist strongly with a high fracture density (0.6-3 m spacing).

The predominant NW trend of the main Carboniferous joint sets is coincident with the present day maximum horizontal stress direction (145/325을 Evans \& Brereton 1990). Rogers (2003) predicted that the stress-induced fracture permeability is likely to be higher along this trend in the current UK stress field.

\section{Mineralogy}

The Barnett Shale has a relatively low clay content (c. 27\%, Jarvie et al. 2004) compared to other shales. The presence of significant amounts of quartz and carbonate in the shale matrix, imparts brittleness to the rock, facilitating artificial fracturing. The $\mathrm{Al}_{2} \mathrm{O}_{3}$ content of UK Carboniferous mudstones ranges between 12-38\%, with an average of around 25\% (Ramsbottom et al. 1981). Marine and non-marine shales in the Tansley borehole have average $\mathrm{Al}_{2} \mathrm{O}_{3}$ contents of $20.6 \%$ and $17.9 \%$ respectively, with clay minerals making up 59\% and 56\% of the shale matrix (Spears \& Amin 1981).

\section{Gas Fields and Discoveries}

The presence of conventional gas fields in Carboniferous and Jurassic basins (Fig. 1) demonstrates that gas has been generated(Figure 1). In a few cases there is unambiguous evidence of the source being Namurian shales (e.g. the Elswick Gasfield)), because Coal Measures are absent in the subcrop (Fig. 3, Smith 1985). In some gas fields migration could have occurred from either a Coal Measures source or from Namurian strata uplifted in an inverted basin (e.g. Nooks Farm). Along the southern margin of the Cleveland Basin (the Ryedale gas fields) a third migration direction, along E-W faults, from the Southern North Sea, is also a possibility. 
Gas wetness (percentage of non-methane gas) values (Fig. 45) are high when gas is associated with oil in the source rock and lower $(<5 \%)$ when the gas has been exclusively derived from coal-rich strata, is biogenic or post mature. Jarvie et al. (2004) typified two gas samples in the Barnett Shale as post mature dry gas, with gas wetness values of around 5\%: in contrast oil associated gas had values over 12\%. In the Carboniferous of the UK, high values measured at Welbeck Colliery are associated with oil shows, but at nearby Thoresby Colliery (also associated with oil) the gas is rich in methane and was probably sourced from the Coal Measures (Challinor 1990).

Insufficient gas composition and carbon isotope data were available to resolve the migration directions in most gas fields. Carbon and hydrogen isotope data from samples accompanying water flows within shallow tunnels in Namurian strata (Fig. $\underline{6} 6$ ) suggest that the methane either had a biogenic (modern) origin or formed through $\mathrm{CO}_{2}$ reduction (Bath et al. 1988). The US Antrim Shale and New Albany Shale (Fig. 5, Illinois) have late generation biogenic gas systems related to glacial meltwater ingress via fractures (Schurr \& Ridgley 2002).

\section{Principal Source Rocks}

Two lithostratigraphic units from the Mississippian represent potential shale gas plays in the UK, these are the Craven Group found in the Pennine Basin and the Lower Limestone Shale around the Mendips. The Craven Group comprises a thick sequence of interbedded limestone and shale. The Pennine Basin formed to the north of the Wales-Brabant massif: this geological and tectonic setting is not a direct tectonic analogue to the Barnett Shale. Conversely the Lower Limestone Shale was deposited in a similar tectono-stratigraphic setting to the Barnett, in the foreland of the Variscan Front, west of the Worcester Graben. It thickens southward from 35 m north of the Severn Estuary to 170 m in the Mendips (Kellaway \& Welch 1948) and is also present south of the Bristol Channel.

The Pennine Basin has been the focus of extensive coal and hydrocarbon exploration in the past, consequently a comprehensive database is available to evaluate shale gas potential in the region. The Craven Group (Mississippian) ranges in thickness from >1450 m in the Craven sub-basin to >5000 m in the Widmerpool Gulf (Waters et al. 2007). The mudstones were deposited in distal slope turbidite and hemi-pelagic environments in relatively narrow, deep depocentres in the Widmerpool Gulf, North 
Staffordshire Basin, Edale Gulf, Gainsborough Trough, Craven Basin and Stainmore Trough.

Individual shale units that might represent potential source rocks include (Table 1) the Worston Shale Group, the Long Eaton Formation and the Widmerpool Formation. The latter has a high TOC content in Duffield borehole (Fig. 67), but the gamma ray values are low (Aitkenhead 1977). Younger shale gas targets include the Bowland (Edale) Shales and the Sabden Shales (Namurian). The condensed black Bowland Shale sequence outcropping in the Derbyshire Peak District is thin and immature for hydrocarbon generation, but these units thicken to the east and represent the main source rocks that charged the East Midlands hydrocarbon system. In the Tansley borehole, TOC content averaged 4.48\% in marine bands and 2.66\% in non-marine shale sequences (Fig. 2). A gamma ray peak is found close to the base of the Arnsbergian sequence, extending down into the Pendleian. In the Uppertown borehole this interval coincides with phosphatic nodules and collophane, in a sequence of dark grey shale, containing abundant fossilised plants. Ponsford (1955) recorded higher than average radioactivity in these shale units in the Castleton borehole. The gross thickness of the Upper Bowland Shale (Namurian), together with the net thickness of high-gamma shale layers, is shown for most of the hydrocarbon wells (Fig. 7)8.

The Sabden Shales are characterised by anomalously low density and velocity on wireline logs, which is indicative of high organic matter content. Overpressure caused by disequilibrium compaction or volume expansion related to hydrocarbon generation (Osborne \& Swarbrick 1997) can also cause anomalous velocity-density trends. Core samples indicate that the unit predominantly comprises hard, dark grey to black micaceous mudstone with abundant plant fossils. The presence of interbedded coal seams suggests that at least part of the sequence may be gas-prone. TOC measurements in the Knott Coppy borehole are in the range 1-3\%, making these shale units potential hydrocarbon source rocks, however in this borehole TOC-rich shales do not always correspond to high gamma intervals.

\section{Jurassic Black Shales}

Black shales are found in the three main Jurassic mudstone formations: the Lias, Oxford Clay and Kimmeridge Clay (Fig. 1). Liassic shales form the main source rocks for the Wessex and Weald oilfields (Ebukanson \& Kinghorn 1986). These shales are mature for gas generation and small gas 
accumulations (dubbed 'enigmatic' by Butler \& Pullan 1990) occur on the margins of the Weald Basin and associated with oil at Wytch Farm in the Wessex Basin (Fig. 1). In northern England the Lias is within the oil window in the Cleveland Basin. The Oxford and Kimmeridge Clay contain organic-rich formations and might also prove to be potential source rocks in basins.

Porosity and permeability values are likely to be higher in Jurassic shale units because they have not been subject to as much compaction as Palaeozoic shale formations. Jurassic mudstones encountered in shallow ( $<30 \mathrm{~m}$ ) engineering boreholes have porosities in the range 30-40\%. Organic rich shale units are preferentially enriched in $\mathrm{Cu}, \mathrm{Ni}, \mathrm{V}, \mathrm{Ag}$ and $\mathrm{Mo}$ (Gad et al. 1969) in common with shales of Palaeozoic age.

\section{Conclusions}

At the regional scale the Mississippian Bowland Shale Formation provides the most prospective shale gas play. The Bowland Shale is a proven source rock mature for gas production. Locally, shales of Lower Palaeozoic (principally Upper Cambrian) and Jurassic age might prove suitable targets. BGS are currently developing a black shales database and GIS covering the UK. This will synthesize most of the available hydrocarbon data relevant for shale gas exploration. However, additional data are required to minimize exploration risk. In particular, isotope studies of gas source provenance and more information on joint and fracture densities are required. Shale gas is most likely to occur in the sub-basin depocentres of the Pennine and Weald basins. Those shales, which have not sourced conventional hydrocarbons, need to be carefully evaluated to see if they can make a contribution. Most conventional hydrocarbon exploration wells test structural highs and fault traps, with the result that some entirely miss source rocks known from other wells or interpreted from seismic. Wells drilled in the depocentres and the greater attention to shales required for this unconventional exploration are likely to lead to a new surge in subsurface geological knowledge of the UK

\section{Acknowledgements}

This paper is published with the permission of the Executive Director of the British Geological Survey (NERC). We thank S Holloway and M Stephenson for improving drafts and D Entwisle for providing porosity data. 


\section{References}

Aitkenhead, N. 1977. The Institute of Geological Sciences Borehole at Duffield, Derbyshire. Bulletin of the Geological Survey of Great Britain, 59.

Armstrong, J. P., Smith, J., D’Elia, V.A. A. \& Trueblood, S. P. 1997. The occurrence and correlation of oils and Namurian source rocks in the Liverpool Bay-North Wales area. In: Meadows, N. S., Trueblood, S. P., Hardman, M. \& Cowan, G. (Eds) Petroleum geology of the Irish Sea and adjacent areas. Geological Society Special Publication No. 124, 195-211

Bath, A., Darling, W. G., Hitchman, S. P., Andrews, J. N., Cave, M. R., Green, K. A. \& Reeder, S. 1988. Chemical and stable isotopic analyses of dissolved gases and groundwater seepages collected from Wyresdale Tunnel, November 1987. WE/88/1C.

Bowker, K. A. 2007. Barnett shale gas production, Fort Worth Basin: issues and discussion. American Association of Petroleum Geologists, 91, 4, 523-533.

Budge, G. D. 1932. Methane storage in strata. Proceedings of the South Wales Institute of Engineers, 48, $177-200$.

Butler, M. \& Pullan, C. P. 1990. Tertiary structures and hydrocarbon entrapment in the Weald Basin of southern England. In: Hardman, R. F. P.\& Brooks, J. (Eds) Tectonic events responsible for Britain’s oil and gas reserves. Geological Society Special Publication, 55, 371-391.

Challinor, P. J. 1990. Oil ingress into mine workings. The Mining Engineer, August 1990, 68-74.

Creedy, D. P. 1989. Geological sources of methane in relation to surface and underground hazards. Paper 1.4 Methane- facing the problems. Symposium Nottingham 26-28 ${ }^{\text {th }}$ September.

Dow, W. G. 1977. Kerogen studies and geological interpretations. Journal of Geochemical Exploration, 7, 2, 77-79.

Dow, W. G. \& O'Connor, D. E. 1982. Kerogen maturity and type by reflected light microscopy applied to petroleum exploration. In: Staplin, F. L., Dow, W. G., Milner, C. W. D., O'Connor, D. I., Pocock, S. A., Van Gijzel, J. P., Welte, D. H. \& Yukler, M. A. (Eds), How to Assess Maturation and Paleotemperatures Short Course No. 7. Society of Economic Paleontologists and Mineralogists, 133157.

Earp, J. R. \& Hains, B. A. 1971. The Welsh Borderland. British Regional Geology Memoir of the British Geological Survey. 
Ebukanson, E. J. \& Kinghorn, R. R. F. 1986. Oil and gas accumulations and their possible source rocks in southern England. Journal of Petroleum Geology, 9, 4, 413-428.

Evans, C.J. \& Brereton, N.R., 1990. In situ crustal stress in the United Kingdom from borehole breakouts, in Hurst, A., Lovell, M.A., and Morton, A.C.,( Eds)., Geological applications of wireline logs: Geological Society of London Special Publication, 48, 327-338.

Ewbank, G., Manning, D. A. C. \& Abbott, G. D. 1993. An organic geochemical study of bitumens and their potential source rocks from the South Pennine Orefield, central England. Organic Geochemistry, 20, 5, 579-598.

Ferguson. J. 1984. The methane content of some Carboniferous limestones from the northern Pennines and its relationship to mineralisation: Proceedings of the Yorkshire Geological Society 45, (1-2), 67-69 Frantz, J. H., Waters, G. A. \& Jochen, V. A. 2005. Operators re-discover shale gas value. E\&P, October 2005.

Fraser, A. J., Nash, A. J., Steele, R. P. \& Ebdon, C. C. 1990. A regional assessment of the intraCarboniferous play of northern England. In: J. Brooks (Ed.) Classic Petroleum Provinces. Special Publication No. 50, 417-440.

Gad, M. A., Gatt, J. A. \& Le Riche, H. H. 1969. Geochemistry of the Whitbian (Upper Lias) sediments of the Yorkshire coast. Proceedings of the Yorkshire Geological Society, 37, 105-139.

Griffith, A. E. 1983. The search for petroleum in Northern Ireland. In: Brooks, J. (Ed.) Petroleum geochemistry and exploration of Europe, 213-222.

Hillier, S. \& Marshall, J. E. A. 1992.Organic maturation, thermal history and hydrocarbon generation in the Orcadian Basin, Scotland. Journal of the Geological Society, London, 149, 491-502.

Hitchman, S. P., Darling, W. G. \& Williams, G. M. 1990. Stable isotope ratios in methane containing gases in the United Kingdom. BGS Technical Report, WE/89/30.

Hood, A, Gutjahr, C. C. M. \& Heacock, R. L. 1975. Organic metamorphism and the generation of petroleum. American Association of Petroleum Geologists, 59, 6, 986-996.

Jarvie, D., Pollastro, R., Hill, R., Bowker, K., Claxton, B. \& Burgess, J. 2004. Evaluation of hydrocarbon generation and storage in the Barnett Shale, Fort Worth Basin, Texas. Humble website. Jones, D. G. \& Plant, J. A. 1989. Geochemistry of shales. In: Plant, J. A. \& Jones, D. G. (Eds) Metallogenic models and exploration criteria for buried carbonate-hosted ore deposits - a multidisciplinary study in eastern England. 65-94. 
Kellaway, G. A. \& Welch, F. B. A. 1948. Bristol and Gloucester district. British Regional Geology. British Geological Survey.

Landes, K.K. 1967. Eometamorphism, and oil and gas in time and space. Bulletin of the American Association of Petroleum Geologists, 51, 6, 1, 828-841.

Leggett, J. K 1980. British Lower Palaeozoic black shales and their palaeo-oceanographic significance. Journal of the Geological Society, 137, 2, 139-156.

Lokhurst, A. (Ed) 1998. The Northwest European Gas Atlas. - Composition and Isotope Ratios of Natural Gases in Northwest European Gasfields. NITG-TNO, Haarlem. (CD ROM).

Maynard, J. R., Wignall, P. B. \& Varker, W. G. 1991. A hot new shale facies from the Upper

Carboniferous of Northern England. Journal of the Geological Society, 148, 5, 805-808.

Moseley, F. \& Ahmed, S. M. 1967. Carboniferous joints in the north of England and their relation to earlier and later structures. Proceedings of the Yorkshire Geological Society, 36, 1, 4, 61-90.

Oldroyd, G. C., McPherson, M. J. \& Morris, L. H. 1971. Investigations into sudden abnormal emissions of firedamp from the floor strata of the Silkstone Seam at Cortonwood Colliery. The Mining Engineer, 130, 9, 577-593.

Osborne, M. J. \& Swarbrick, R. E. 1997. Mechanisms for generating overpressure in sedimentary basins: a reevaluation. Bulletin of the American Association of Petroleum Geologists, 81, 6, 1023-1041 Parnell, J. 1983. The distribution of hydrocarbon minerals in the Welsh Borderlands and adjacent areas. Geological Journal, 18, 129-139.

Plant, J. A. \& Jones, D. G. 1989. Metallogenic models and exploration criteria for buried carbonatehosted ore deposits - a multidisciplinary study in eastern England. British Geological Survey and the Institution of Mining and Metallurgy.

Pollastro, R.M., Hill, R. J., Ahlbrandt, T. A., Charpentier, R. R., Cook, T. A., Klett, T., Henry, R. M. E. \& Schenk, C. J. 2004. Assessment of undiscovered oil and gas resources of the Bend Arch-Fort Worth Basin Province of North-Central Texas and Southwestern Oklahoma, 2003: U.S. Geological Survey Fact Sheet 2004-3022, available online at: http://pubs.usgs.gov/fs/2004/3022/

Ponsford, D. R. A. 1955. Radioactivity studies of some British sedimentary rocks. Bulletin of the Geological Survey, 10, 24-44.

Poole, E. G. 1977. Stratigraphy of the Steeple Aston Borehole, Oxfordshire. Bulletin of the British Geological Survey, 57. 
Poole, E. G. 1978. Stratigraphy of the Withycombe Farm Borehole, near Banbury, Oxfordshire.

Bulletin of the British Geological Survey, 68.

Ramsbottom, W. H. C., Sabine, P. A., Dangerfield, J. \& Sabine, P. W. 1981. Mudrocks in the

Carboniferous of Britain. Quarterly Journal of Engineering Geology, 14, 257-262.

Ray, E. O. 1976. Devonian shale development in eastern Kentucky. In: Natural Gas from

unconventional geologic sources. Board on Mineral Resources and Commission on Natural Resources. $100-111$.

Rogers, S. F. 2003. Critical stress-related permeability in fractured rocks. In: Ameen, M (Ed.) Fracture and In-situ Stress Characterization of Hydrocarbon Reservoirs. Geological Society, London Special Publication, 209, 7-16.

Rushton, A. W. A., Hamblin, R. J. O. \& Strong, G. E. 1988. The Croft Borehole in the Lilleshall Inlier of north Shropshire. Report of the British Geological Survey, 19, 3.

Shurr, G. W. \& Ridgley, J. L. 2002. Unconventional shallow biogenic gas systems. Bulletin of the American Association of Petroleum Geologists, 86, 11, 1939-1969.

Selley, R. C. 1987. British shale gas potential scrutinized. Oil and Gas Journal, June 15th.62-64.

Selley, R. C. 2005. UK shale-gas resources. In: Dore, A. G. \& Vining, B. A. (Eds). Petroleum geology: Northwest Europe and global perspectives- Proceedings of the $6^{\text {th }}$ Petroleum Geology Conference, 707-714. Geological Society, London.

Smith, N. J. P. (Compiler) 1985. Map 1: Pre-Permian Geology of the United Kingdom (South). 1:1,000,000 scale. British Geological Survey.

Smith, N. J. P. 1993. The case for exploration of deep plays in the Variscan fold belt and its foreland. In: Parker, J. R. (ed.) Petroleum geology of Northwest Europe:Proceedings of the 4th Conference. Geological Society, London. 667-675.

Smith, N. J. P. \& Rushton, A. W. A. 1993. Cambrian and Ordovician stratigraphy related to structure and seismic profiles in the western part of the English Midlands. Geological Magazine, 130, 5, 665-671.

Smith, N. J. P., Kirby, G. A. \& Pharaoh, T. C. 2005. Structure and evolution of the south-west Pennine Basin and adjacent area. Subsurface Memoir of the British Geological Survey Spears, D. A. \& Amin, M. A. 1981. Geochemistry and mineralogy of marine and non-marine Namurian black shales from the Tansley borehole. Sedimentology, 28, 407-417. 
Stocks, A. E. \& Lawrence, S. R. 1990. Identification of source rocks from wireline logs. In: Hurst, A.,

Lovell, M. A. \& Morton, A. C. Geological applications of wireline logs. Geological Society Special Publication, 48, 241-252.

Taylor, K. \& Rushton, A. W. A. 1971. The pre-Westphalian geology of the Warwickshire Coalfield.

Bulletin of the Geological Survey of Great Britain, 35.

Waters, C. N., Browne, M. A. E., Dean, M. T. \& Powell, J. H. 2007. Lithostratigraphical framework for Carboniferous successions of Great Britain (onshore). British Geological Survey, RR/07/01.

Zhao, H., Givens, N. B. \& Curtis, B. 2007. Thermal maturity of the Barnett Shale determined from well-log analysis. American Association of Petroleum Geologists Bulletin. 91, 4, 535-549.

\begin{tabular}{rrrr}
\hline Formation & Equivalents & Stages & Basin \\
\hline Kimmeridge Clay & & Kimmeridgian & Weald \\
\hline Oxford Clay & & Callovian-Oxfordian & Weald \\
\hline Lias & Edtangian-Toarcian & Weald \\
\hline Sabden Shales & Arnsbergian & Pennine \\
\hline Upper Bowland Shale & Pendleian & Pennine \\
\hline Lower Bowland Shale & Widmerpool Formation & Brigantian & Pennine \\
\hline Worston Shale & Hodder Mudstone & Chadian-Holkerian & Craven \\
\hline Long Eaton Formation & & Chadian-Asbian & Widmerpool \\
\hline Other names & & Namurian & NE Wales \\
\hline Holywell Shale & Pentre Chert, Bowland & & \\
\hline Craven Group & Shale & Pennine
\end{tabular}

Table 1. Names of main black shale formations and their equivalents

The Craven Group is a new term, extending from Courceyan to Yeadonian stages which has rendered a lot of the local names in the Carboniferous obsolete for stratigraphic purposes (Waters et al. 2007).

\section{Figure captions}

Fig. 1. Main hydrocarbon source rocks (outcrops). Wells reaching Tremadoc to Cambrian in England and hydrocarbon wells in northern Ireland which tested a tight gas Carboniferous play in several phases (Griffith 1983) as recently as 2001.

Fig. 2. Variation of TOC contents in the Carboniferous of northern England.

Gleaston borehole is in south Cumbria, Ferneyrigg, Stonehaugh and Marshall Meadows are in the Northumberland Trough, Roddymoor is on the Alston Block and Beckermonds is on the Askrigg Block. The other boreholes are in the Pennine Basin. 
Fig. 3. Vitrinite reflectance percentage values obtained nearest to the base Namurian.

Yellow spots are immature for hydrocarbons, green represents early part of oil window, orange late part of oil window (cf. Barnett Shale top of gas window), red the gas window and grey overmature. Most existing hydrocarbon wells were drilled on structural highs and likely to possess lower maturity than the potential source rock.

Fig. 4. Gas wetness ratio of analysed gases.

The gases associated with oilfields have higher gas wetness values (a greater percentage of higher hydrocarbons). Welbeck Colliery has a high gas wetness, suggesting perhaps some gas from sources other than Coal Measures. These values suggest that source rocks, which have sourced the gas, exist in strata other than Coal Measures. However potential shale gas is likely to be nearer to dry methane within deeper parts of the half graben.

Fig. 5. Carbon and hydrogen isotope ranges in various methane gases.

$\delta^{13} \mathrm{C}$ values 0 to -20\% are probably abiogenically-derived (e.g. Fischer-Tropsch reactions with hydrogen). $\delta^{13} \mathrm{C}$ values -20 to about $-55 \%$ represent thermogenic methane. The gasfield methanes (Lokhurst 1998) are migrated gases. Coalfield gases (Hitchman et al. 1989) might be more depleted than the migrated gases, with biogenic and $\mathrm{CO}_{2}$-reduced gases (Bath et al. 1986) even more depleted. BC Barnsley Coal, BPS Bridport Sandstone, CB Cornbrash, SSG Sherwood Sandstone Group, LIAS Lower Lias organic matter Arreton, NC Nottinghamshire Coalfield Deep Soft Coal, SNS Southern North Sea, WL West Leigh, WT Wyresdale Tunnel.

Fig. 6. Range of total organic carbon contents and vitrinite reflectance in the BGS Duffield borehole, Widmerpool Gulf. NAM Namurian, DIN Dinantian, \%Ro vitrinite reflectance.

The high Ro\% near the base is caused by igneous sills but may lead to gas window maturity near or below terminal depth.

Fig. 7. Upper Bowland Shale: gross thickness of mudstones and net thickness of high gamma mudstones. 


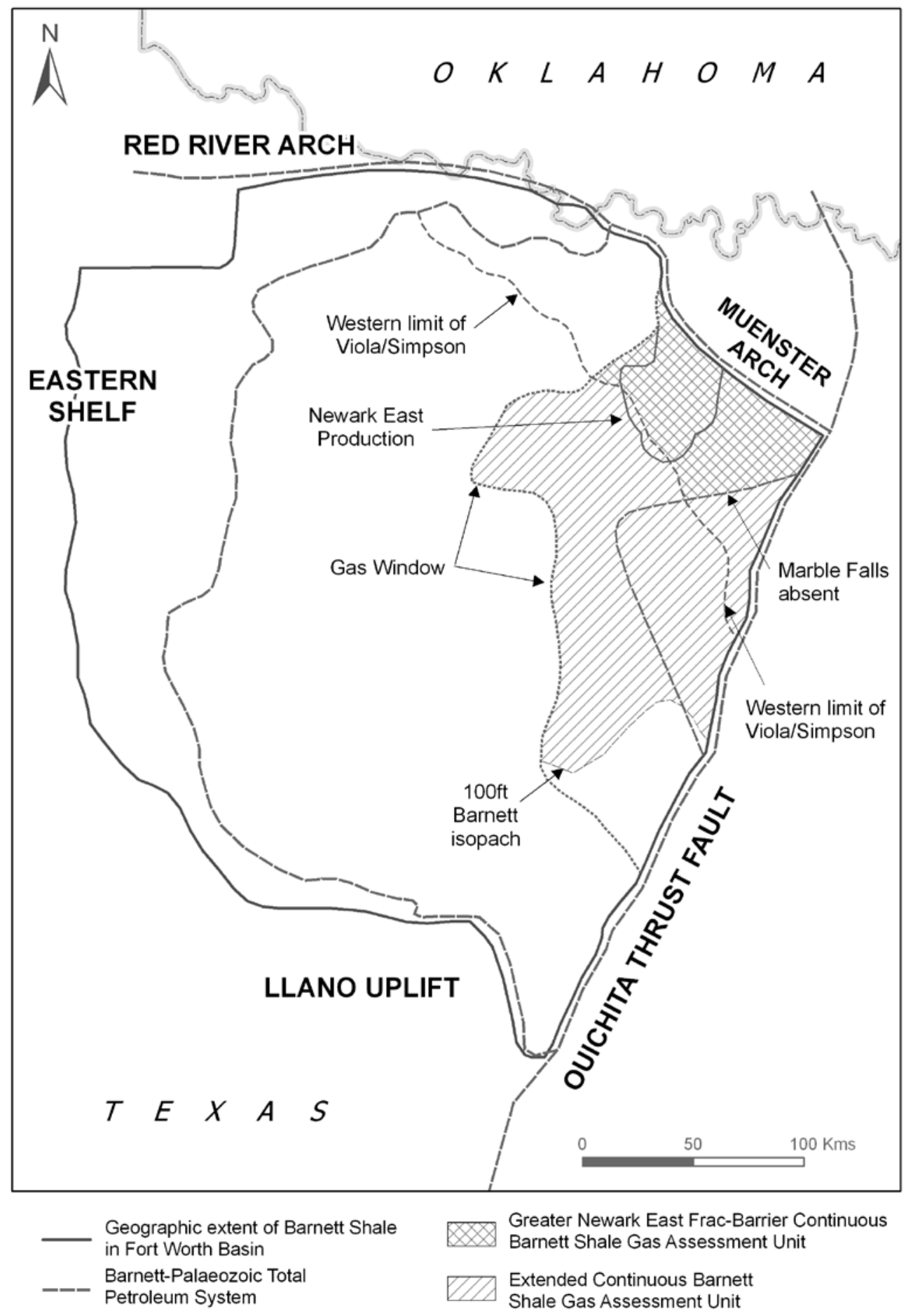

Fig. 1 


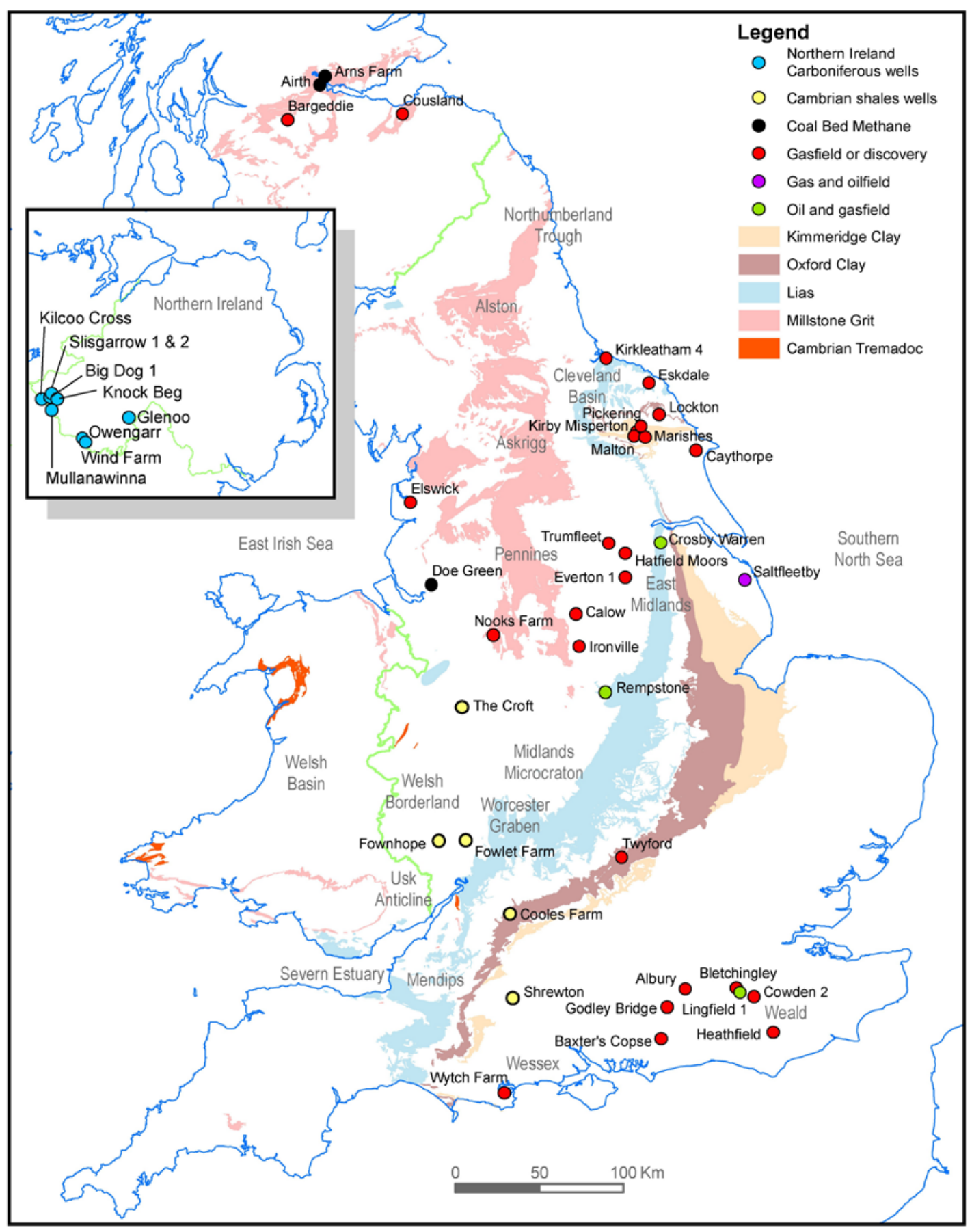

Fig. 2 


\begin{tabular}{|c|c|c|}
\hline \multirow{3}{*}{ 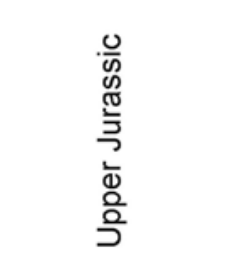 } & \multicolumn{2}{|l|}{ Kimmeridge Clay } \\
\hline & Corallian & \\
\hline & Oxford Clay & \\
\hline Middle Jurassic & Great Oolite Group & \\
\hline Lower Jurassic & Lias & \\
\hline Triassic & Mercia Mudstone Group & \\
\hline$\subseteq$ & Sherwood Sandstone Group & Group \\
\hline$\frac{\infty}{\sqrt{d}}$ & Coal Measures & \\
\hline$\overline{0}$ & Millstone Grit Group & \\
\hline Mississippian & Carboniferous Limestone & \\
\hline Devonian & Black Shale in Orcadian Basin & \\
\hline Silurian & Black Shale in fold belt & \\
\hline Ordovician & Black Shale in fold belt & $\begin{array}{l}\text { Bowland } \\
\text { High Group }\end{array}$ \\
\hline Upper Cambrian & $\begin{array}{l}\text { White-Leaved-Oak Shales/ } \\
\text { Monks Park Shales }\end{array}$ & \\
\hline
\end{tabular}

Fig. 3 


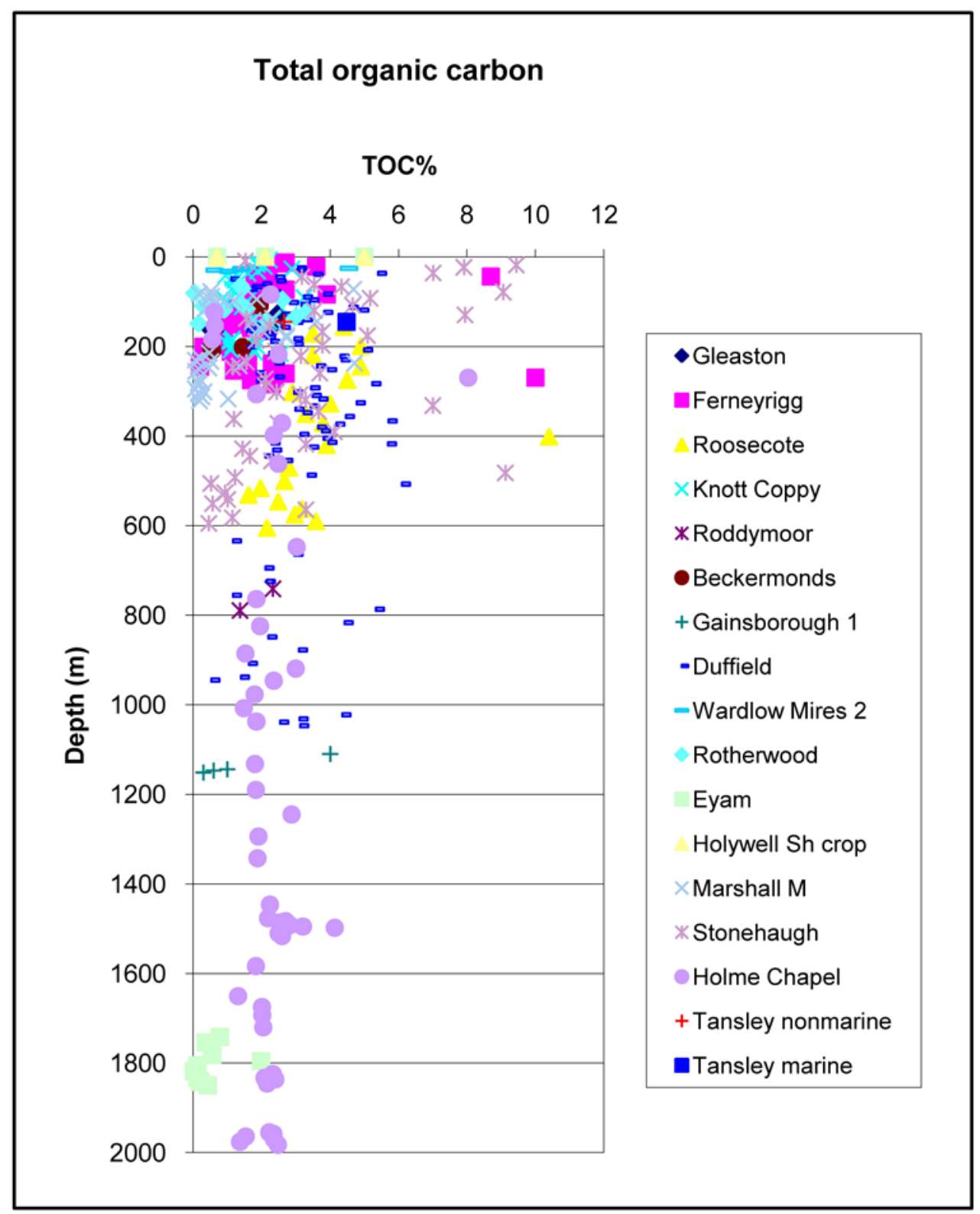

Fig. 4 


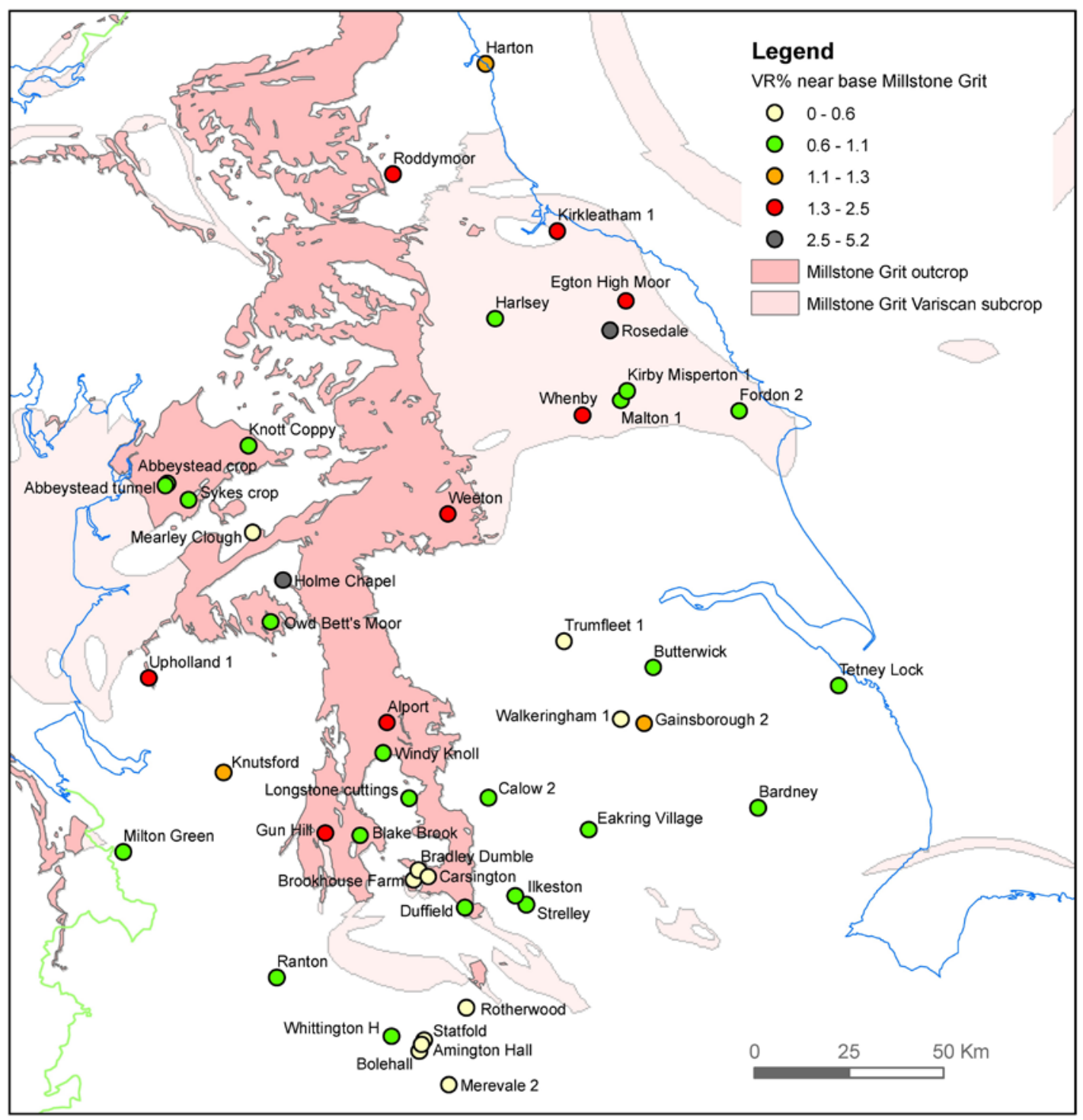

Fig. 5 


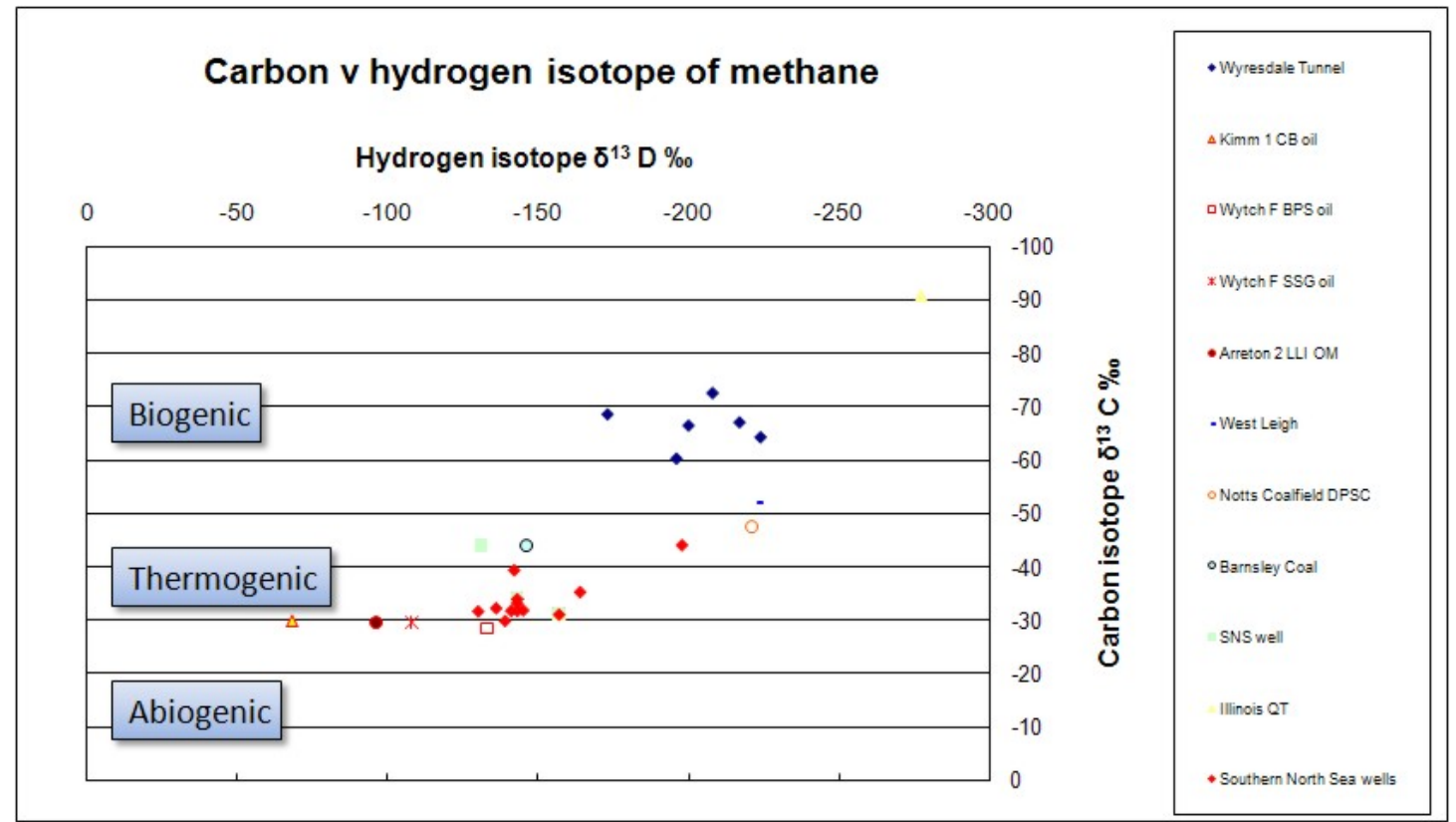

Fig. 7

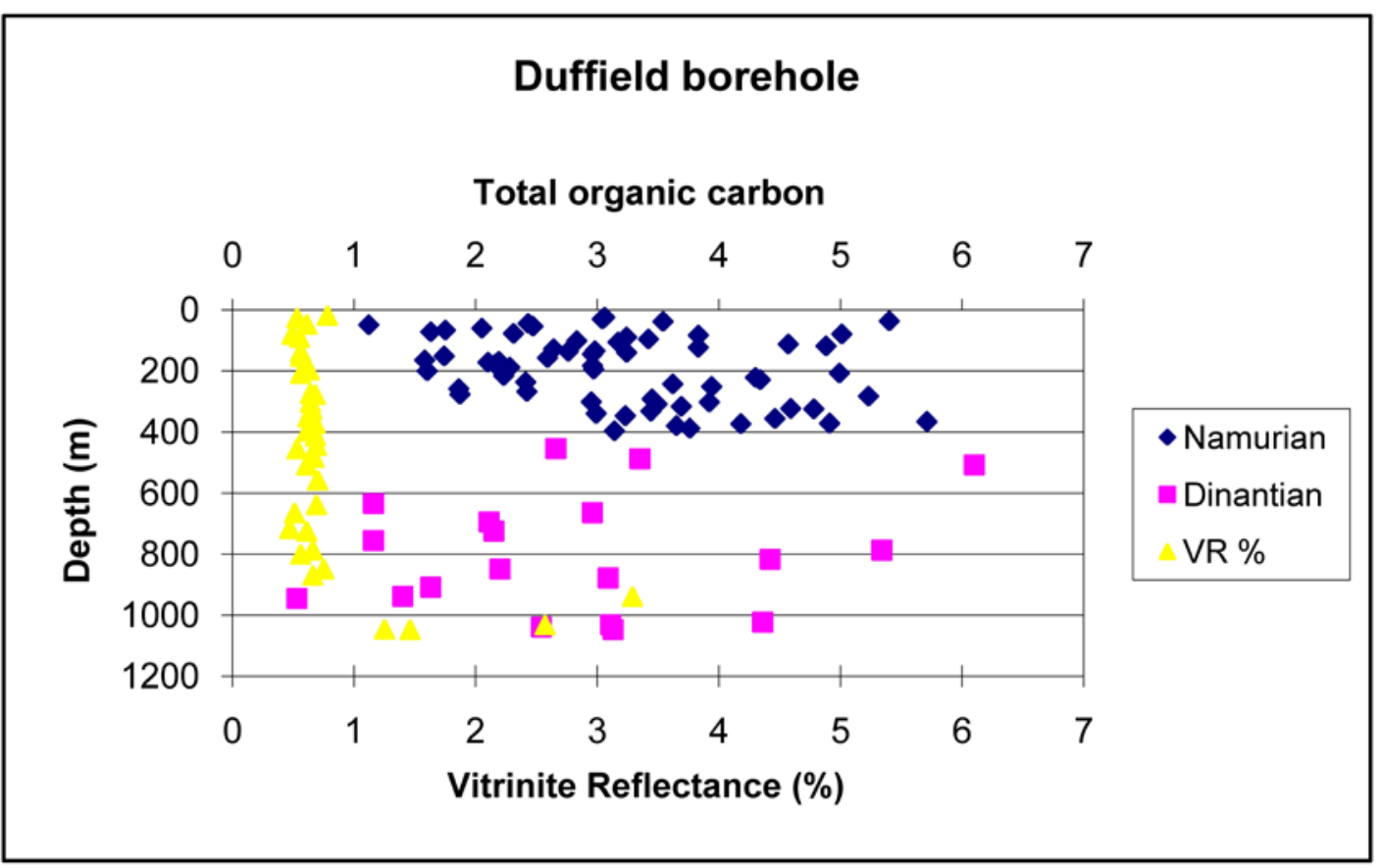

Fig. 8 


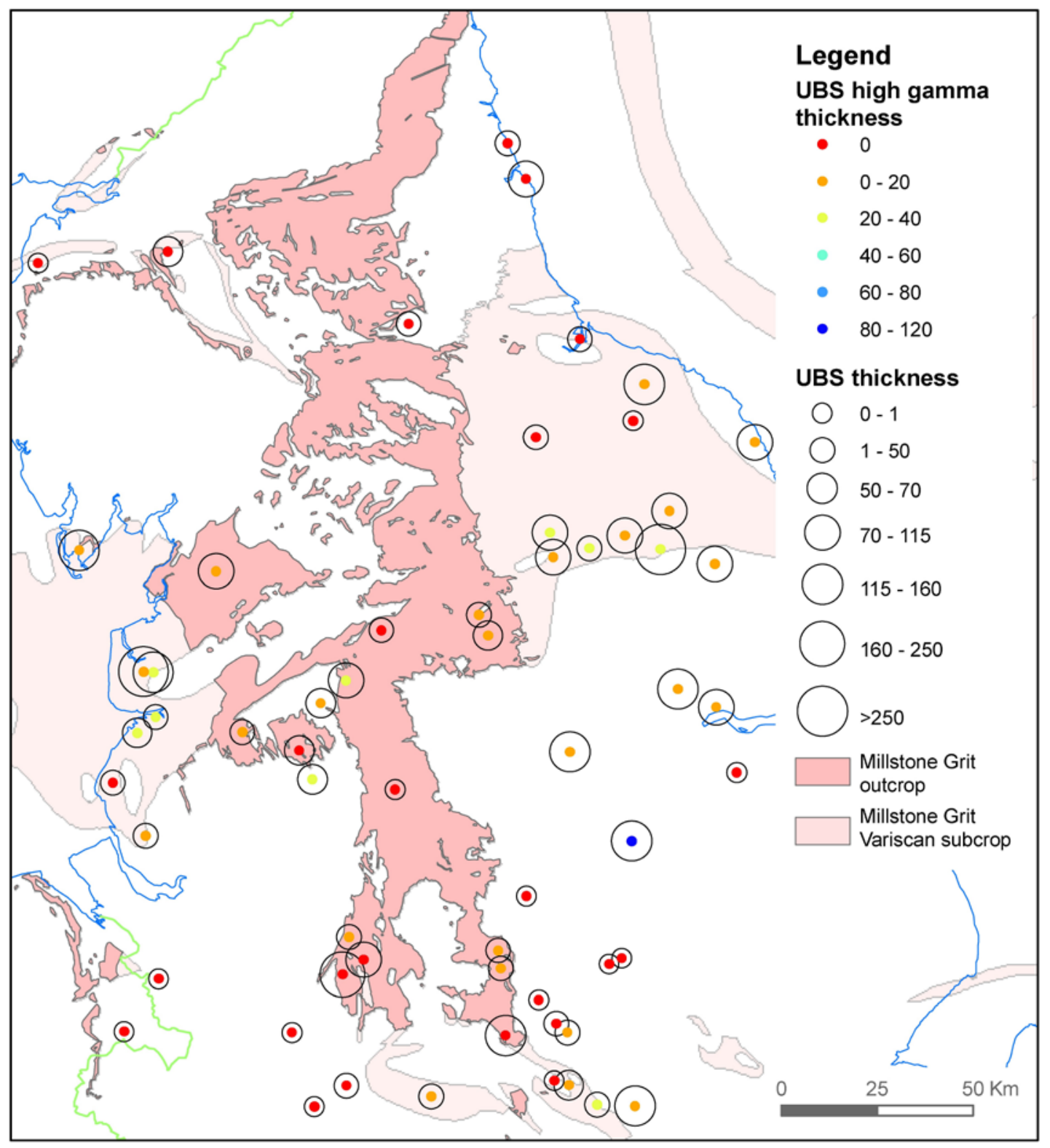

Fig. 9 